\title{
Important Dates Post-1989
}

\section{0}

21 September Arikha picture 'Sam's spoon'.

5 October Achevé d'imprimer of the first translation into French of Proust.

\section{1}

22 May Under the heading 'Wills' The Independent reports 'Mr Samuel Barclay Beckett, of Paris, the author and playwright, left an estate valued at $£ 15,376$ net'.

\section{2}

27 November Publication of Dream of Fair to Middling Women (Black Cat Press, Dublin, in association with Faber and Faber).

\section{4}

22 December Achevé d'imprimer of the first translation into French of More Pricks Than Kicks: Bande et Sarabande.

\section{5}

23 February First French publication of Eleutheria.

\section{6}

26 September Publication of James Knowlson's Damned to Fame: the Life of Samuel Beckett.

\section{9}

Street named after SB in the XIVème arrondissement in Paris on the 10th anniversary of his death. 